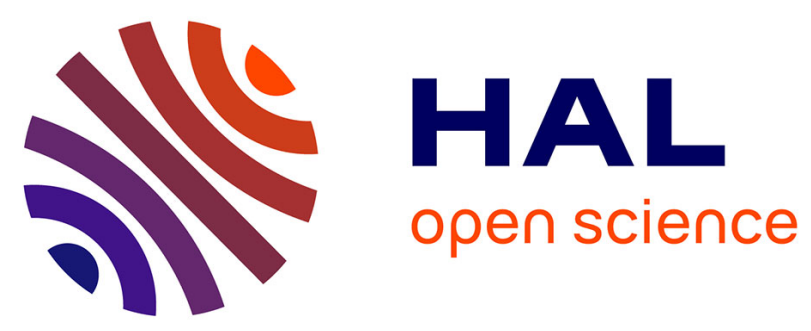

\title{
COMPUTATION OF POROSITY REDISTRIBUTION RESULTING FROM THERMAL-CONVECTION IN SLANTED POROUS LAYERS
}

\author{
Philippe Gouze, Anne Coudrain, Dominique Bernard
}

\section{To cite this version:}

Philippe Gouze, Anne Coudrain, Dominique Bernard. COMPUTATION OF POROSITY REDISTRIBUTION RESULTING FROM THERMAL-CONVECTION IN SLANTED POROUS LAYERS. Journal of Geophysical Research: Solid Earth, 1994, 10.1029/93JB02450 . ird-01230580

HAL Id: ird-01230580

https://hal.ird.fr/ird-01230580

Submitted on 18 Nov 2015

HAL is a multi-disciplinary open access archive for the deposit and dissemination of scientific research documents, whether they are published or not. The documents may come from teaching and research institutions in France or abroad, or from public or private research centers.
L'archive ouverte pluridisciplinaire HAL, est destinée au dépôt et à la diffusion de documents scientifiques de niveau recherche, publiés ou non, émanant des établissements d'enseignement et de recherche français ou étrangers, des laboratoires publics ou privés. 


\title{
Computation of porosity redistribution resulting from thermal convection in slanted porous layers
}

\author{
Philippe Gouze ${ }^{1}$ \\ Centre Géologique et Géophysique, Université de Montpellier II, France \\ Anne Coudrain-Ribstein \\ Laboratoire de Géologie Appliquée, Université Pierre et Marie Curie, Paris, France \\ Dominique Bernard \\ Ecole Nationale Supérieure d'Arts et Métiers, Université de Bordeaux I, Talence, France
}

\begin{abstract}
Unlike fluid displacement due to regional hydraulic head, thermoconvective motions are generally slow. The thermal impacts of such movements are very weak, whereas their chemical impacts may be significant because of their cumulated effects over geologic time. For nonhorizontal thick sedimentary reservoirs, the fluid velocity due to thermal convection can be accurately approximated by an explicit function of the dip of the reservoir, the permeability and the difference in thermal conductivity between the aquifer and the confining beds. The latter parameter controls the rotation direction of the flow and, for clastic reservoirs bounded by impervious clayey media, fluid moves up the slope along the caprock layer. As the fluid velocity is small, the major rock-forming minerals control the fluid composition by thermodynamic equilibrium. Thus, whereas the volume of redistributed minerals depends on the volume of water circulated, the localization of porosity enhancement is strongly controlled by the reservoir mineralogy. With realistic values of permeability and layer thickness, several per cent of secondary porosity per million years can be created or lost at shallow depth $(<2 \mathrm{~km})$, depending on the chlorinity, the set of representative minerals and the temperature. In sandstone reservoirs and high-chlorinity calcarenite reservoirs, the porosity decreases under the caprock where hydrocarbons can accumulate. In chloride-depleted carbonate aquifers, the simultaneous control by carbonates, silica and aluminosilicates can produce a decrease of porosity above the bedrock and an enhancement of porosity under the caprock. However, computations show that the quality of the upper part of the reservoir is mainly reduced by the precipitation of silica and clays.
\end{abstract}

\section{INTRODUCTION}

Redistribution of mineral material and creation of secondary porosity, due to dissolution and precipitation of carbonates, silica and aluminosilicates are widely observed in petroleum reservoirs and aquifers. In unconfined aquifers, hydraulic head gradients controlled by land surface elevation dominate over buoyancy forces. These fluid motions constitute the principal mode of reactive solute transport over significant distances, far superior to molecular diffusion processes. In confined reservoirs disconnected from superficial hydraulic head gradients, many authors have suggested that thermoconvective fluid movements are significant mechanisms in the transport of reactive solutions [Straus and Shubert, 1977; Wood and Hewett, 1982, 1984; Bjorlykke et al., 1988; Bethke, 1989; Palm, 1990; Criss and Hofmeister, 1991; Phillips, 1991; Ludvigsen and Palm, 1992]. In this case, motion is controlled by the evolution of the fluid density due to temperature patterns in the reservoir.

\footnotetext{
${ }^{1}$ Also at Laboratoire de Géologie Appliquée, Université Pierre et Marie Curie, Paris, France.

Copyright 1994 by the American Geophysical Union.
}

Paper number 93JB02450

$0148-0227 / 94 / 93 \mathrm{JB}-02450 \$ 05.00$
Although little thermal evidence of thermoconvective currents has been found [Combarnous and Aziz, 1970; Blanchard and Sharp, 1985; Genthon et al., 1990], it is difficult to demonstrate such fluid movements in low-enthalpy environments because fluid velocities are too small to significantly affect the conductive thermal pattern [Menegazzi, 1989]. Despite the weakness of such fluid motion, the redistribution of mineral species into rock-forming layers may provide evidence of past or present thermoconvective movements. This mineral localization is the consequence of diagenesis caused by reactive fluid migration persisting over geologic time [Coudrain-Ribstein and Marsily, 1989]. Fluid or mineral stratifications possibly linked to convective movements have already been studied by Tardy and Cassan [1981], Rabinowicz et al. [1985] and Bjorlykke et al. [1988]. Because such closed systems are potential reservoirs, the vertical distribution of secondary porosity has a major impact on the distribution of the hydrocarbons that may eventually accumulate in the reservoir [Wood and Hewett, 1984]. The purposes of this paper are (1) to describe the fluid velocity distribution in realistic sedimentary inclined reservoirs, (2) to quantify the ability of such large cellular motion of fluid to redistribute minerals vertically using representative chemical systems and (3) to point out the necessity of modeling simultaneously the interdependent chemical reactions in order to draw conclusions about porosity redistribution. 


\section{THERMal CONVECTION IN POROUS} SLOPING LAYER

In a porous layer, assumed to be continuous and rigid, saturated with fluid and bounded by impermeable beds, the temperature dependence of fluid density can produce buoyancy forces that set fluid in motion [Combarnous and Bories, 1975]. Usually, fluid driving forces are characterized by the filtration Rayleigh number which expresses the ratio between the motion and the stabilizing forces for a given geometry (Appendix 1). The fact that clastic reservoirs are generally tilted from a few to 20 degrees and have a thermal conductivity which differs from impervious surrounding beds implies that isotherms are almost never perpendicular to the direction of gravity even if the regional geothermal gradient is vertical. In this case, the fluid saturating the aquifer is always unstable, and the value of the Rayleigh number does not control the occurrence of thermoconvective fluid motion but governs the amplitude and the stability domain of the geometrical configuration of the cell(s) (Figure 1). In the most general case the velocity field is computed with the help of numerical tools to solve mass and energy conservation equations, Darcy's law and state equation [Bernard, 1988a; Combarnous and Bernard, 1988]. In sedimentary stacking, the strata are generally characterized by a large ratio of the lateral extent versus thickness, which commonly ranges between 100 and 1000. In this case, for normal values of thermal gradients and layer dip angles of less than 30 degrees, a steady state single-cell regime is predicted (Figure 1 and 2), and the thermoconvective movements can be modeled in the plane parallel to the slope [Menegazzi, 1989; Bernard and Menegazzi, 1990]. When hydraulic conductivity is large enough, a wide single-cell develops across the entire system, and the velocity vectors are parallel to the wall except locally, at the edges of the layer, where the transverse component of the velocities dominates. In the large portion of the system where the velocity is parallel to the wall, the specific discharge $\left(U_{x}\right)$ is given by the analytical solution [Bernard, 1988b] (Figure 2):

$$
U_{x}=V k_{x} y
$$

with

$$
V=\frac{\Lambda-1}{\Lambda} \cos (\phi) \sin (\phi) \alpha G
$$

In (1), $k_{x}$ is the longitudinal permeability and $y$ is the transverse coordinate which ranges from $-H / 2$ to $H / 2$, with $H$ the layer thickness. In (2), $G$ is the average geothermal gradient prevailing outside the porous layer, $\phi$ is the dip angle and $\Lambda$ is the ratio between the thermal conductivity of the porous medium $\lambda_{p}$ and that of the impervious surrounding medium $\lambda_{i}$. In this equation, $\alpha$ is a pressure-temperature dependent parameter which describes the properties of the fluid saturating the porous medium:

$$
\alpha=\frac{\rho_{f} \beta_{f} g}{\mu_{f}}
$$

where $\rho_{f}$ is the density, $\mu_{f}$ is the dynamic viscosity and $\beta_{f}$ is the volumetric thermal expansion coefficient of the fluid phase. Results of numerous two- and three-dimensional numerical modeling studies [Menegazzi, 1989; Bernard and Menegazzi, 1990] give the range of validity for the use of (1) and establish that this formulation gives a good approximation ( $\pm 5 \%$ ) of $U_{x}$ in the very large portion of the layer where $\vec{U}$ is parallel to the impervious boundaries (Figure 2) as long as the ratio of length versus thickness (aspect ratio) of the layer is greater than $10 \sqrt{k_{x} / k_{y}}$, where $k_{x}$ and $k_{y}$ are, respectively, the longitudinal and the transverse components of the permeability tensor [Castinel and Combarnous, 1975; Wooding, 1978; Bernard et al., 1989; Menegazzi, 1989].

Resulting to (2), the rotation direction of the flow is determined by the sign of $\{\Lambda-1\}$. The thermal conductivities of the saturated porous medium and the impervious surrounding medium both depend on the proportion of water in the porous media, the mineral composition and the bulk temperatures. Impervious media are mainly composed of clays, as opposed to reservoirs which are usually clastic. Estimates of $\Lambda$ for different temperatures and porosities using extreme values for the thermal conductivities of clastic

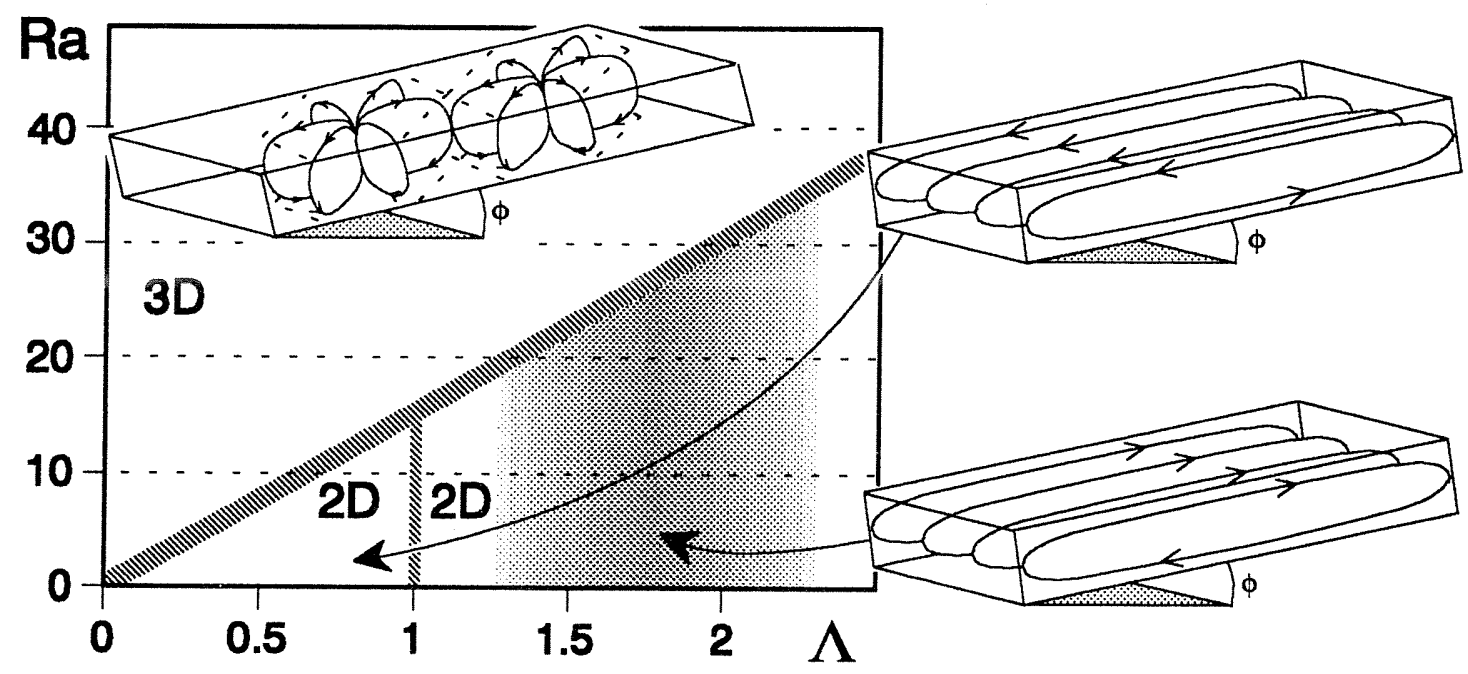

Fig. 1. Rayleigh number $(R a)$ versus conductivity ratio $\left(\Lambda=\lambda_{p} / \lambda_{i}\right)$. Boundaries of each stability domain are drawn on the basis of two- and three-dimensional numerical experiments [Menegazzi, 1989; Bernard and Menegazzi, 1990]. The upper domain corresponds to three-dimensional (3D) flow (the real shape of the cells dependents on boundary conditions, geometry, dip angle, and the sketch is only one of a possible configurations [Riahi, 1983]). The two-dimensional domains (2D) correspond to stable single-cell flow. The rotation direction is a function of the sign of $(1-\Lambda)$. The grey zone corresponds to the values of $\Lambda$ for clastic reservoirs, assuming that the surrounding impervious media are mainly composed of clays. 

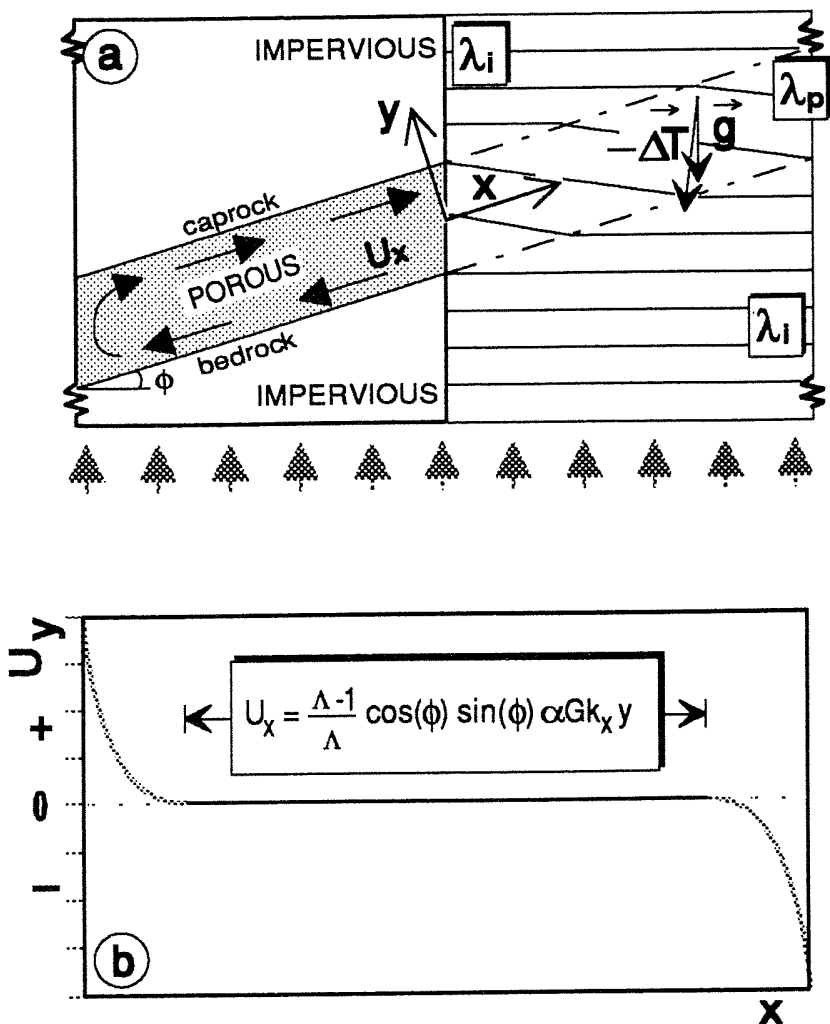

Fig. 2. Geometry and boundary conditions of the studied configuration. (a) The porous layer has a tilt of $\phi$ and is surrounded by impervious beds. The fluid rotation direction (left side) and the thermal pattern (right side) are schematized for single-cell flow when $\Lambda>1$ and for a uniform vertical heat flux. (b) Transverse velocity $\left(U_{y}\right)$ versus $x$ axis. For single-cell configuration, $U_{x}$ can be accurately approximated by the given formulation in the large domain where transverse velocity $U_{y}$ is negligible.

and clayey lithologies [Horai, 1971; Cermak and Rybach, 1982; Brigaud and Vasseur, 1989] show that this parameter is always greater than 1 , the most common values ranging from 1.8 to 2.3 . Thus, the rotation direction of the fluid is imposed with a descending flow in the lower half of the layer $(y<0)$ and an ascending current beneath the caprock $(y>0)$ (Figure 2). For example, assume a 200 -m-thick layer dipping at $10^{\circ}$, a permeability of 70 mdarcy $(7 \mathrm{X}$ $10^{-14} \mathrm{~m}^{2}$ ) at a depth of $2000 \mathrm{~m}$ with a conductivity ratio $(\Lambda)$ of 2.2 , the velocity (equations (1) and (2)) immediately under the caprock (point A, in Figure 3) is $+3.5 \times 10^{-10} \mathrm{~m} \mathrm{~s}^{-1}\left(\sim 1 \mathrm{~cm} \mathrm{y}^{-1}\right)$.

The temperature is not significantly influenced by fluid motion within the reservoir. The temperature field is steady state and controlled by thermal conduction. According to the coordinate convention described in Figure 2, the expression of temperature is

$$
\begin{gathered}
T(x, y)=T_{0}+G\left(-x \sin (\phi)-\frac{y}{\Lambda} \cos (\phi)\right) \\
\text { MODEL OF FLUID-MINERAL REACTIONS } \\
\text { AND SOLUTE TRANSPORT }
\end{gathered}
$$

\section{MODEL OF FLUID-MINERAL REACTIONS AND SOLUTE TRANSPORT}

With values of permeability and layer thickness lower than 0.5 Darcy and $300 \mathrm{~m}$ respectively, calculations using (1) show that the specific discharge is always smaller than $0.1 \mathrm{~m} \mathrm{y}^{-1}$ for a large range of geothermal gradients $\left(20^{\circ}\right.$ to $\left.60^{\circ} \mathrm{C} \mathrm{km}^{-1}\right)$ and depths $(1$ to $5 \mathrm{~km})$.
Thus, the fluid residence time at the mineral surfaces is large, and the relations between the chemistry of the solution and the constituent minerals can be accurately described by the assumption of local thermodynamic equilibrium (Appendix 2). A consequence of this hypothesis is that the local chemical speciation can be computed as a function of the thermodynamic constraints of mineral-fluid equilibria and of transport controlled variables such as temperature and chlorinity. The geochemical system, including minerals and soluble species is characterized by a set of stoichiometric reactions:

$$
E_{j} \leftrightarrow \sum_{i=1}^{N_{c}} v_{i, j} E_{i}
$$

where $E_{i}$ belongs to a set of $N_{c}$ independent species called components [Morel, 1983] and $E_{j}$ is one of the other species not taken as a component and called secondary species. The reactions are characterized by a thermodynamic equilibrium constant $K_{j}$ :

$$
K_{j}(T)=\frac{\prod_{i=1}^{N_{c}}\left(\gamma_{i} C_{i}\right)^{v_{i, j}}}{C_{j} \gamma_{j}}
$$

where $C_{i}, C_{j}$ are, respectively, the concentration of a component and of a secondary species and $\gamma_{i}$ is the activity coefficient of the $i$ th component. In this study, equilibrium constants are taken from data bases by Fritz [1981], Michard [1983] and Nordstrom et al. [1990]. The system is totally described by these stoichiometric relations and $N_{c}$ constraints, including the mineral-fluid equilibrium relations [Coudrain-Ribstein, 1988]. For convenience, to interpret chemical analyses of fluid, the most common set of components is formed by the $N_{c}$ simple ionic species, but any other set of independent species can be used, for example including minerals [Coudrain-Ribstein and Jamet, 1989].

Assuming that temperature and chlorinity pattems are controlled by steady state transport in a saturated and homogeneous porous medium, the description of the macroscipic mass conservation equation can be expressed as given by Marsily [1986]:

$$
\bar{\nabla} \cdot\left(D \cdot \bar{\nabla} C_{i}^{T}-\bar{U} C_{i}^{T}\right)-\Omega_{i}=0
$$

where the sink/source term $\Omega$ has the dimension of a mass per unit rock volume and per unit time. In (7), $D$ is the dispersion tensor for the equivalent continuous medium and $C_{i}^{T}$ is the total concentration at equilibrium of the $i$ th component defined according to the expression

$$
C_{i}^{T}=C_{i}+\sum_{j} v_{i j} C_{j}
$$

For a given set of components, the total concentration of a solute component is the quantity that has to be added to pure water in order to achieve the composition under observation. If the $i$ th component is a mineral, the sink/source term $\Omega_{i}$ quantifies the mass exchange between the fluid and the mineral [Coudrain-Ribstein, 1988].

Assuming that dispersion effects are negligible (this assumption will be discussed later), $\Omega$ is a linear function of $U$. Rearranging (1), (4), (7) and (8), the formulation of $\Omega_{i}$, in the zone of the tilted layer where $U_{y}=0$, is

$$
\Omega_{i}(y)=G \sin (\phi) \frac{\partial C_{i}^{T}}{\partial T} V k_{x} y
$$


If the surface temperature is fixed, $\Omega_{i}(y)$ is a function of four independent parameters $\left(\Lambda, \phi, T\right.$ and $\left.k_{\mathbf{x}}\right)$ and of two temperature-dependent parameters $\left(C_{i}^{*}\right.$ and $\left.\alpha\right)$. Results are obtained by solving (6)-(8) using the Newton-Raphson method and by solving (7), which is spatially discretized in two dimensions, using the finite element method [Coudrain-Ribstein, 1988;Goblet, 1989]. In (7) the spatial distribution of parameter $U_{x}$ is imposed according to (1) and (2). If the $i$ th component is a mineral and $w_{i}$ its molal volume, then $\Omega_{i} t$ and $\left(\sum \Omega_{i} w_{i}\right) t$ represent, respectively, the transfer of mineral and the secondary porosity created during the period $t$. Figure 3 shows the variation of porosity as a function of the $y$ distance, for a given geochemical system, a given depth, and the following reference values of the parameters:

$$
\begin{aligned}
\partial U_{x} / \partial y & =V k_{x}=1 \mathrm{~s}^{-1} \\
G & =30^{\circ} \mathrm{C} \mathrm{km}^{-1} \\
\phi & =20^{\circ} ; \\
H & =320 \mathrm{~m} .
\end{aligned}
$$

The total variation of porosity $\Delta \omega / \Delta t$ is a linear function of $V$ and $k_{x}(\operatorname{see}(9))$. As $\Delta \omega / k_{x} U \cos (\phi)$ is a constant, the porosity variation

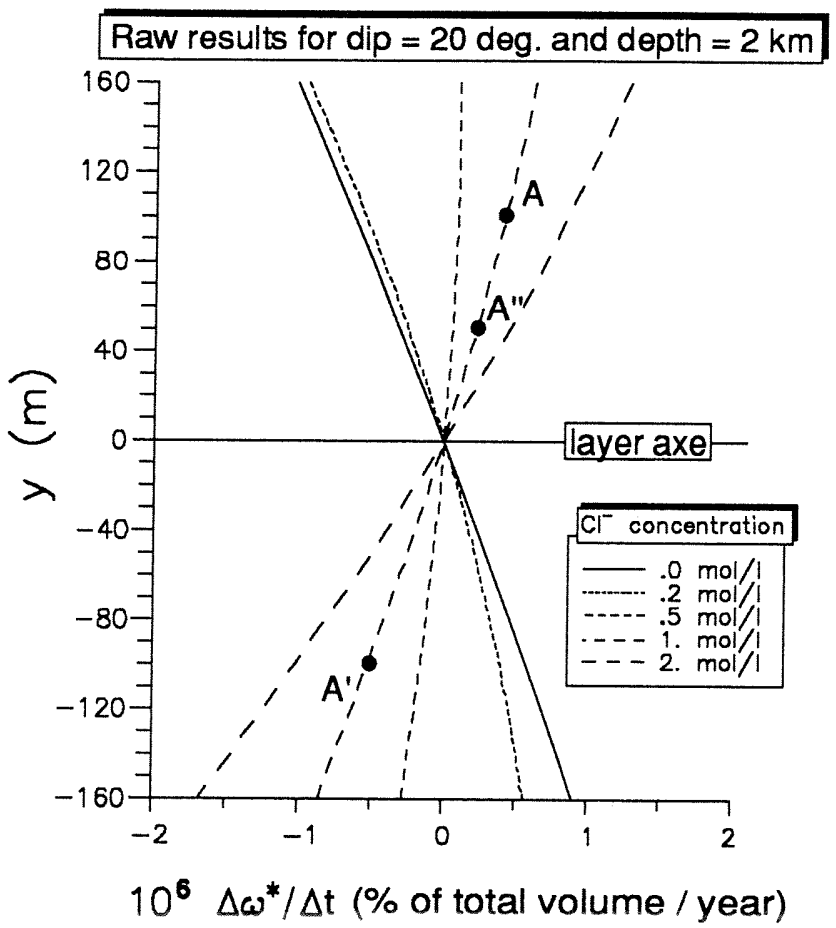

Fig. 3. Example of porosity variation $\left(\Delta \omega^{*} / \Delta t\right.$ in percent of the total volume per year) versus the distance $y$ to the central axis of the permeable layer. $\Delta \omega^{*} / \Delta t$ is computed by solving (9) for parameter reference values: $V k_{x}=1 \mathrm{~s}^{-1}, \phi=20^{\circ}$, depth $=2000 \mathrm{~m}$ and $G=30^{\circ} \mathrm{C} \mathrm{km}^{-1}$. $\Delta \omega^{*} / \Delta t$ represents an increase in porosity if $<0$ and a decrease if $>0$. Results are given for different chlorinities $\left(0\right.$ to $\left.2 \mathrm{~mol} \mathrm{~L}^{-1}\right)$ for the calcarenite model. For given values of $V k_{x}$ (equation (1)) and $\phi$, the value of $\Delta \omega / \Delta t$ can easily be calculated by (10). For example, let assume a 200 -m-thick layer, a chlorinity of $1 \mathrm{~mol} \mathrm{~L}^{-1}$ (point $\mathrm{A}$ ) and a fluid velocity immediately under the caprock $(y=+100 \mathrm{~m})$ of $+3.5 \mathrm{X}$ $10^{-10} \mathrm{~m} \mathrm{~s}^{-1}$. The graph gives $\Delta \omega^{*} / \Delta t_{A}=+0.4810^{6} \% \mathrm{y}^{-1}$ wich correspond (equation (10)) to a porosity decrease of $0.85 \%$ of the total volume per My. Similarly, in A', immediately above the bedrock, a porosity increase of $0.94 \%$ of the total volume per My can be computed $\left(U=-3.5 \times 10^{-10} \mathrm{~m} \mathrm{~s}^{-1}\right)$. At $y=+50 \mathrm{~m}\left(\mathrm{~A}^{\prime \prime}\right)$, the fluid velocity is $1.7510^{-10}$ $\mathrm{m} \mathrm{s}^{-1}\left(U_{A^{\prime \prime}}=1 / 2 U_{A}\right)$, and the model predict a porosity decrease of 0.45 $\%$ of the total volume per My. resulting from any combination of these parameters can be calculated by the relation

$$
\frac{\Delta \omega(y)}{\Delta t}=\frac{\Delta \omega^{*}(y)}{\Delta t} k_{x} V \frac{\sin (\phi)}{\sin (20)}
$$

where $\Delta \omega^{*} / \Delta t$ is the porosity evolution for reference parameters and where $V k_{\mathrm{x}}$ have the same time unit as in the reference case $\left(\mathrm{s}^{-1}\right)$. Furthermore, because the velocity is a linear function of the distance to the $x$ axis, the rate of porosity increase $(\Delta \omega / \Delta t<0)$ or decrease $(\Delta \omega / \Delta t>0)$ is directly calculated at the distance $y$ of the axis by (10). Consequently, only geochemical parameters and depth have to be investigated, the latter because of the dependence of $\partial C / \partial T$ on $T$. The evaluation of the regional thermal gradient $(G)$, the fluid characteristic $(\alpha)$ and the transverse permeability $\left(k_{x}\right)$, and then, the application of (1), (2) and (10) to reference results $\left(\Delta \omega^{\circ}(y)\right)$, as illustrated by Figure 3, permits the calculation of the rate (for example, in percentage of the total volume per million years) of porosity increase or decrease for an extensive range of potential configurations.

\section{SIMULATIONS OF THE DIAGENESIS ASSOCIATED WITH THERMOCONVECTION}

\section{Mineral Redistribution and Secondary Porosity}

Although many fluid-mineral reactions have been reported [see, Michard, 1989; Moore, 1989; Nagy et al., 1990; Nordstom et al., 1990], the volumetrically important ones in terms of porosity evolution for clastic reservoirs are those including silica, carbonates, $\mathrm{K}$-feldspar, albite and clays as authigenic or detrital fractions [North, 1985; Giles and Boer, 1990]. In the present study, three geochemical systems are investigated: a speculative model of pure quartz and two realistic models corresponding to arkosic facies (carbonate-free environments) and calcarenite facies. Table 1 lists the components of each geochemical model. The parameters controlling the fluid velocity as a function of depth (Figure 4) are arbitrarily fixed to classical values in order to isolate the influence of the geochemical processes on the porosity evolution.

As reservoirs are often quartz dominated, the pure quartz model which simulates $\mathrm{SiO}_{2}$ mass transfer between the fluid and silica is classically used, not only in the case of thermal convection, but also to evaluate secondary porosity created by diagenetic events in aquifers [e.g., Wood and Hewett, 1984; Palm, 1990; Ludvigsen and Palm, 1992]. Porosity changes resulting from this model are controlled by the solubility coefficients of silica and do not depend on chlorinity. According to this model, and because silica solubility increases with temperature, dissolution will always occur in the lower half of the reservoir as fluid warms up when moving downward. Conversely, the primary porosity is cemented by authigenic silica under the caprock where fluid moves toward the crest (Figure 4). Generally, this approach is justified by the fact that quartz cementation and dissolution are often observed and thought to be responsible for an important part of the porosity changes in siliciclastic environments. However, $\mathrm{SiO}_{2}$ exchanges are driven not only by silica solubility but by a set of interdependant chemical reactions. In most cases, aluminosilicates are abundant in the form of clays and feldspars in buried aquifers and reservoirs, and they intervene in the speciation of silicon.

The situation which corresponds to a carbonate-free composition is investigated with the arkosic model (AR curves in Figure $4 b$ and $4 c$ ). In this model, which allows a realistic representation of the fluid-rock interaction in most clastic reservoir environments, the fluid is assumed to be at equilibrium with amorphous silica, 
$\mathrm{K}$-feldspar, albite and kaolinite. At any depth and dip angle, porosity decreases in the upper half of the layer $(y>0)$ and increases in its lower half $(y<0)$. For temperatures of less than some $70^{\circ} \mathrm{C}$, the decrease in porosity in the upper part of the layer is essentially due to silica precipitation. For temperatures above $70^{\circ} \mathrm{C}$, the contribution of K-feldspar precipitation becomes important (Figure 5). Fluid - mineral mass transfer per unit fluid volume increases with depth, but obviously, the rate of porosity enhancement decreases with depth as fluid velocity decreases (Figure 4). If chlorite is added to this paragenesis, the redistribution of chlorite as well as its influence on the transfer of other minerals is negligible.

Carbonates are known to participate in the control of chemical parameters such as $p \mathrm{H}$ and $\mathrm{CO}_{2}$ partial pressure and can thus result in a considerable degree of secondary porosity creation [Giles, 1987; Smith and Ehrenberg, 1989; Hutcheon, 1990]. Their influence on the secondary porosity creation is investigated here with the calcarenite model in which we assume equilibrium with respect to calcite, amorphous silica, $\mathrm{K}$-feldspar, disordered dolomite, albite, anhydrite and two major clay minerals : kaolinite and chlorite. Subjected to convective fluid motion, porosity is enhanced (Figure 4) when fluid flows upward (upper half of the layer) if chlorinity is weak $\left(<0.6 \mathrm{~mol} \mathrm{~L}^{-1}\right.$ or $\left.<20 \mathrm{~g} \mathrm{~L}^{-1}\right)$. For higher values of chlorinity, this feature remains up to a depth which is ruled by temperature gradient. Above this critical temperature, the porosity decreases in the upper half of the layer in the same proportion as in the carbonate-free model. Quantitative (Figure 4) and qualitative (Figures 5 and 6) comparisons between the different models show the importance of taking into account a realistic set of minerals in order to estimate porosity evolution. The quantity of secondary porosity predicted with the pure quartz model is more than 100 times less than that obtained with the other models and shows, for a given depth and chlorinity, an opposite evolution compared to the calcarenite model. For the calcarenite model, the type of matter redistribution changes strongly as a function of depth. For temperatures higher than $60^{\circ} \mathrm{C}$, the major part of the matter redistribution is controlled by reactions with both alumino-silicates and carbonates (Figure 6). Results show the importance of taking into account clayey minerals, not only because they are the most able to occlude porosity and decrease permeability [North, 1985], but also because they contribute to control silicon and aluminum speciation.

\section{Transport by Diffusion}

In the previous section, it was assumed that the effects of dispersion could be neglected compared to convection. As the dissolution and precipitation of minerals are controlled by transport phenomena, for low permeability, the ground water flow velocities are too small to create significant porosity redistribution. For the cases presented in this paper $(R a<35)$, the limit is around $k=10^{-15}$ $\mathrm{m}^{2}(-1$ mdarcy) for a $300-\mathrm{m}$-thick layer which corresponds to a velocity of about $1 \mathrm{~mm} \mathrm{y}^{-1}$ at the edges of the layer. For permeabilities greater than this value, the calculations using (7) are done using a value for diffusion coefficient $d$ of $1.3 \times 10^{-9} \mathrm{~m}^{2} \mathrm{~s}^{-1}$ at $20^{\circ} \mathrm{C}$ and a temperature evolution of this parameter in $1 / T$ following Stokes-Einstein's relation. These simulations allow comparisons between the volume of porosity creation due to pure convection transport ( $\Delta \omega$ discussed previously) and the porosity creation bounded with diffusion $\Delta \omega_{d}$. The results show that the velocity value below which diffusion transport is not negligible compared to convection transport (say $\Delta \omega_{d}>0.1 \Delta \omega$ ) is generally inferior to the limit value under which porosity modification is not significant over the period relevant to thermoconvective processes. Consequently, the assumption that diffusion effects are negligible is correct and validates the use of (9).

\section{Implications for Hydrocarbon Accumulation}

If the porous layer is a potential petroleum reservoir, the localization of secondary porosity creation has a strong implication for hydrocarbon accumulation and exploitation. Accumulation of hydrocarbons can be expected in the upper half of the layer as a consequence of fluid circulation and density differences between the hydrocarbon products and the fluid phase. Furthermore, for a temperature range of $50^{\circ}$ to $180^{\circ} \mathrm{C}$, which covers the hydrocarbon generation window [Price, 1981], the temperature dependence of the solubility of lighter hydrocarbon components $\left(C_{1}-C_{10}\right)$ closely follows the same prograde evolution with respect to temperature as does silica in pure water. Thus, if pore fluid contains dissolved hydrocarbons, they would also concentrate under the caprock where fluid moves toward the crest and cools $(y>0)$. For arkosic environments, this accumulation of light hydrocarbons would occur where the pore space is cemented by about 0.1 to $3 \%$ per million years depending on the depth and the dip angle of the reservoir. For low chlorinity $\left(<0.3 \mathrm{~mol} \mathrm{~L}^{-1}\right)$ and temperature $\left(<100^{\circ} \mathrm{C}\right)$, hydrocarbon accumulation can occur at the location where porosity is enhanced, if the reservoir contains carbonates (Figure 4).

\section{CONCLUSION}

Many aspects must be taken into account to describe the redistribution of matter associated with thermoconvective fluid motion in a closed clastic reservoir. Nevertheless, it has been shown that, for an inclined sedimentary layer of large horizontal extent, a small number of assumptions allows us to successfully and easily describe the geometric and hydraulic dependence of the mass conservation equation governing porosity redistribution. For a porous sandstone layer surrounded by an impervious argillaceous medium, the ratio of thermal conductivities $(\Lambda)$ between the aquifer and the

TABLE 1. Species of the Three Studied Geochemical Systems.

\begin{tabular}{|c|c|c|}
\hline Pure Quartz System & Arkose System & Calcarenite System \\
\hline $\begin{array}{c}\text { chalcedony } \\
\mathrm{H}_{2} \mathrm{O} \\
\mathrm{H}_{4} \mathrm{SiO}_{4} \\
\mathrm{H}_{3} \mathrm{SiO}_{4}^{-} \\
\mathrm{OH}^{-}\end{array}$ & $\begin{array}{c}\text { Pure Quartz System } \\
+ \\
\text { kaolinite } \\
\text { K-feldspar } \\
\text { albite } \\
{[\mathrm{Mg} \text {-chlorite ] }} \\
\mathrm{Al}(\mathrm{OH})_{4}^{-} \\
\mathrm{K}^{+} \\
\mathrm{Na}^{+} \\
\mathrm{Al}^{+++} \\
\mathrm{Al}(\mathrm{OH})^{++} \\
\mathrm{Al}(\mathrm{OH})_{2}^{+} \\
\mathrm{Al}(\mathrm{OH})_{3} \\
\mathrm{KCl}^{+} \\
{\left[\mathrm{Mg}^{++}\right]} \\
{\left[\mathrm{MgOH}^{+}\right]}\end{array}$ & $\begin{array}{c}\text { Arkose System } \\
+ \\
\text { calcite } \\
\text { disordered dolomite } \\
\text { Mg-chlorite } \\
\text { anhydrite } \\
\mathrm{HCO}_{3}^{-} \\
\mathrm{Mg}^{++} \\
\mathrm{Ca}^{++} \\
\mathrm{SO}_{4}^{-} \\
\mathrm{AlSO}_{4}^{+} \\
\left.\mathrm{Al}_{4} \mathrm{SO}_{4}\right)_{2}^{-} \\
\mathrm{CaCO}_{3} \\
\mathrm{CaHCO}_{3}^{+} \\
\mathrm{CaSO}_{4} \\
\mathrm{CO}_{3}^{-} \\
\mathrm{H}_{2} \mathrm{CO}_{3} \\
\mathrm{HSO}_{4}^{-} \\
\mathrm{KSO}_{4}^{-} \\
\mathrm{MgCO}_{3} \\
\mathrm{MgHCO}_{3}^{+} \\
\mathrm{MgSO}_{4} \\
\mathrm{MgOH}^{+} \\
\mathrm{NaCO}_{3}^{-} \\
\mathrm{NaHCO}_{3} \\
\mathrm{CO}_{2}\left(\mathrm{~g}_{3}\right)^{-}\end{array}$ \\
\hline
\end{tabular}

For the arkosic model, the influence on porosity evolution of $\mathrm{Mg}$-chlorite equilibrium is discused in the text. 


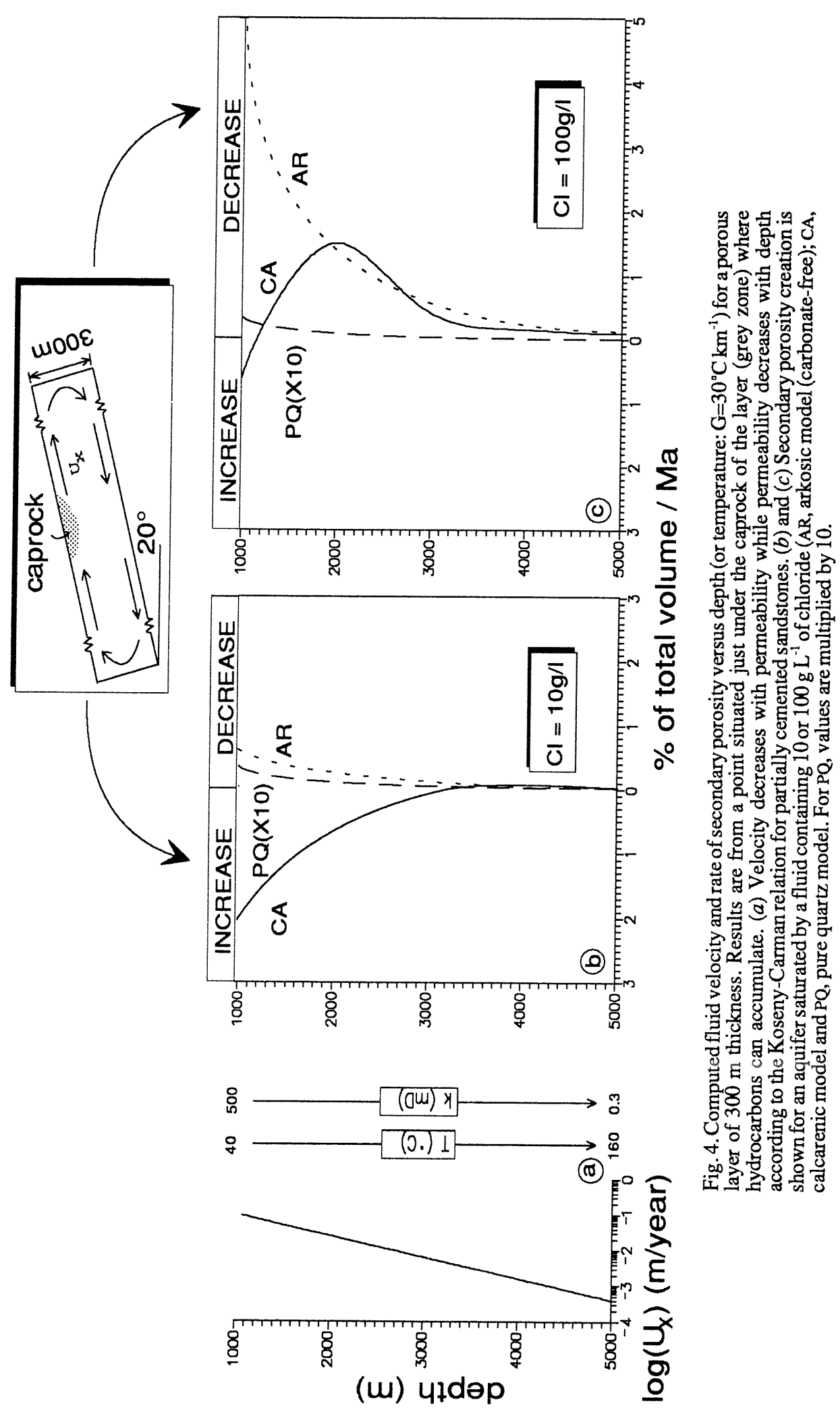



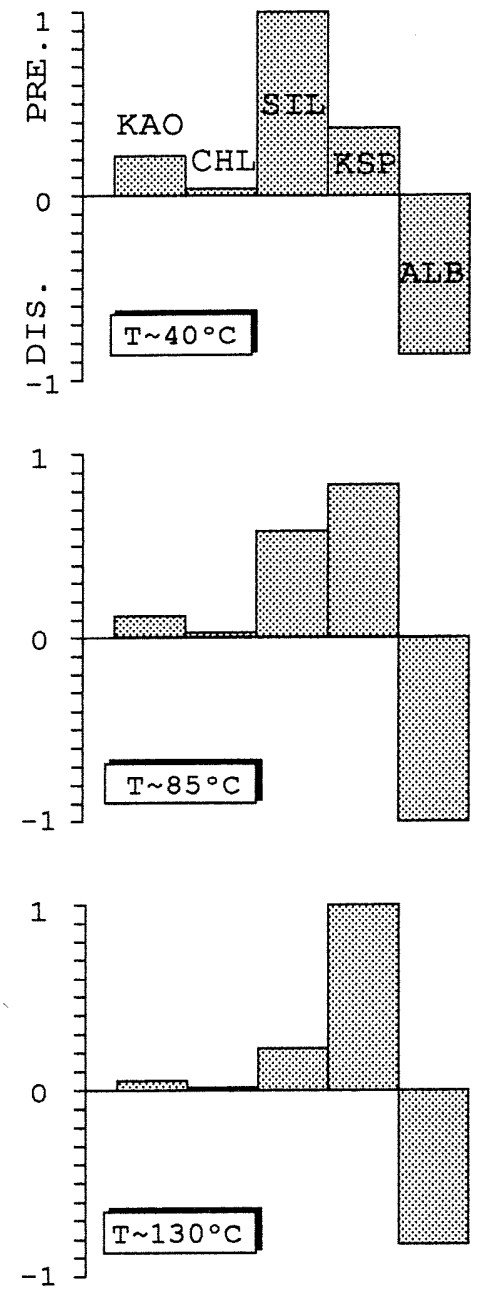

Fig. 5. Molal quantities of dissolved or precipitated minerals for the arkosic model for different temperatures (KAO, kaolinite; $\mathrm{CHL}$, Mg-chlorite; SIL, silica; KSP, K-feldspar and ALB, albite). For each temperature, the values are normalized to the highest value. At low temperatures silica precipitation dominates. For temperatures higher than about $70^{\circ} \mathrm{C}$, aluminum and silicon transfers are mainly due to $\mathrm{K}$-feldspar/albite mass exchanges.

surrounding beds is always greater than 1 , and as a rule, a single - cell fluid motion would occur as an upwelling current in the upper half of the porous layer.

For a given reservoir geometry and composition and a given geothermal gradient, the amplitude of convection is controlled by the evolution with depth of the fluid properties (density, thermal expansion and dynamic viscosity) and the permeability. Local permeability is the strongest constraint on the fluid velocity and, as a result, on the quantity of mineral species redistribution. But, in addition, both the composition of rock-forming minerals and the total chloride content control the direction of porosity alteration (either enhancement or reduction) and the type of cement. Computed results given by a model for a single mineral phase, such as the pure quartz model presented in this article, show that it largely underestimates secondary porosity evolution. The interdependent control of minerals can create large-scale diagenesis $(>1 \%$ over 1 $\mathrm{Ma})$ even for normal geothermal environments $\left(G \sim 30^{\circ} \mathrm{C} \mathrm{km}^{-1}\right)$. Furthermore, the model permits the description of the nature of the cementation and provides important knowledge of the evolution of the reservoir quality. The results obtained by this steady state approach show that thermal convection can be a powerful force for distributing authigenic matter and stratifying preexisting quasi-homogeneous porous layers. Nevertheless, the large quantity of porosity and clay redistribution predicted by this model implies that the sustainment of thermoconvective currents on its initial geometry is certainly hindered by the gradual evolution with time of the permeability resulting from these thermochemical processes.

In rocks containing silica, aluminosilicates and carbonates, which are common in reservoirs, some fluid-mineral reactions become alternatively dominant depending on temperature and chloride content. As a result, although the direction of the fluid rotation is invariable, the porosity evolution along the thickness of the layer may reverse depending on the depth. For low temperatures, clastic reservoirs containing carbonate fractions are subjected to diagenesis which can greatly enhance the porosity under the caprock where hydrocarbons may accumulate. However, for the same permeability, the secondary porosity creation in this zone is greatly decreased for the high chloride contents which often occur in oil field waters.
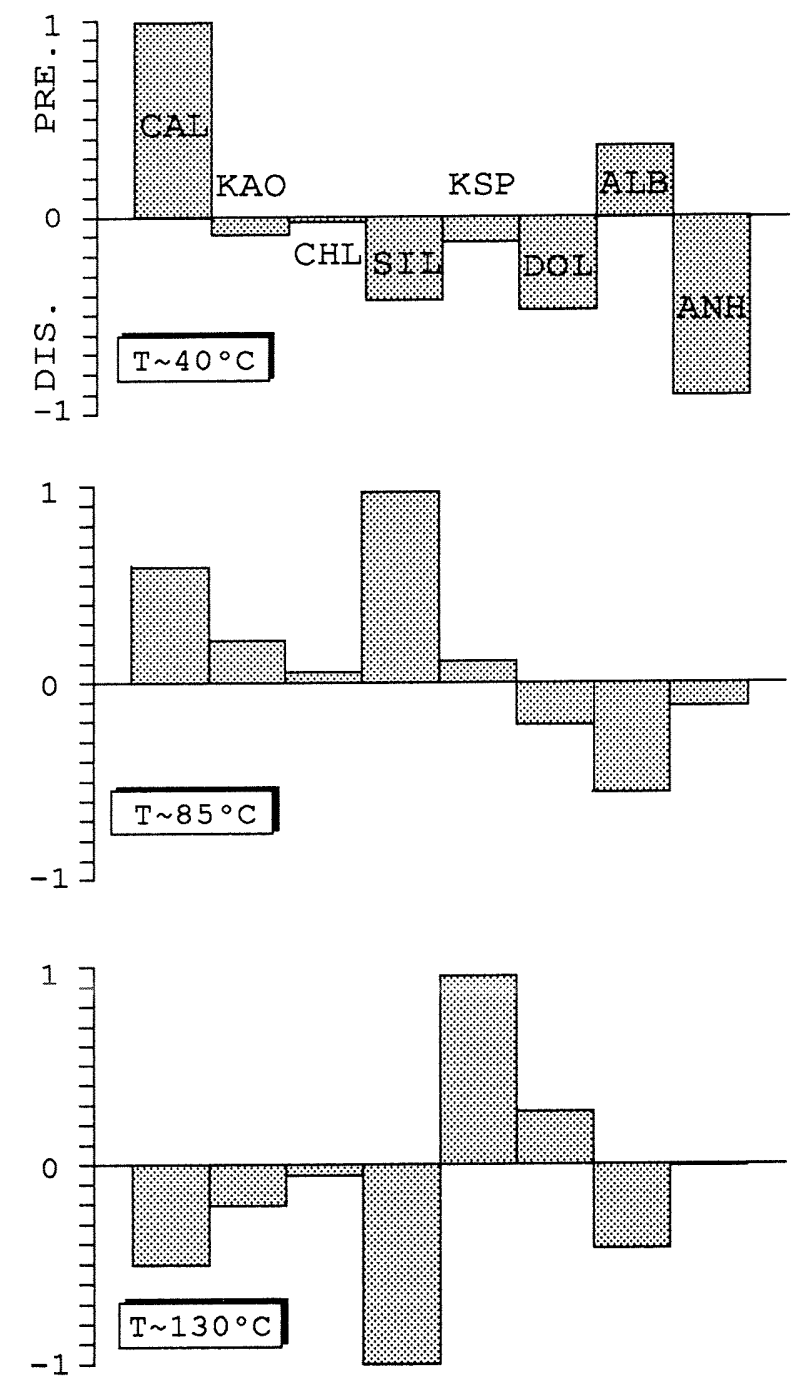

Fig. 6. Molal quantities of dissolved or precipitated minerals for the calcarenite model at different temperatures (CAL, calcite; KAO, kaolinite; CHL, Mg-chlorite; SIL, silica; KSP, K-feldspar; DOL, dolomite; ALB, albite and ANH, anhydrite). For each temperature, the values are normalized to the highest value. The main process is calcite precipitation at $40^{\circ} \mathrm{C}$, silica preripitation at $85^{\circ} \mathrm{C}$ and silica dissolution at $130^{\circ} \mathrm{C}$. 


\section{APPENDIX 1: MATHEMATICAL MODEL FOR FREE CONVECTION}

Assuming Boussinesq's approximations and using the equivalent continuous medium approach, the transfer of fluid and heat through undeformable porous media is described by the following set of equations, here made dimensionless for convenience [Combarnous and Bories, 1975; Combarnous and Bernard, 1988]:

Fluid mass conservation

$$
\bar{\nabla} \cdot \bar{U}^{\prime}=0
$$

Total energy conservation

$$
\frac{\partial T^{\prime}}{\partial t^{\prime}}=\bar{\nabla} \cdot\left(\overline{\bar{\lambda}} \cdot \bar{\nabla} T^{\prime}\right)-\bar{U}^{\prime} \cdot \bar{\nabla} T^{\prime}+q^{\prime}
$$

Darcy's law

$$
\bar{U}^{\prime}=-\bar{k}^{\prime} \cdot\left(\bar{\nabla} p^{\prime}-R a T^{\prime} \bar{Y}\right)
$$

where $\bar{U}$ is the specific discharge, or Darcy's velocity, $T$ is the temperature, $\overline{\bar{\lambda}}$ is the thermal conductivity tensor defined for the equivalent continuous medium, $q$ is the volumetric heat source, $\bar{k}$ is the intrinsic permeability tensor, $p$ is the pressure and $\bar{Y}$ is the vertical axis vector parallel to gravity. All the variables with a prime symbol are dimensionless.

The filtration Rayleigh number $R a$ (defined for the equivalent continuous medium) is the ratio of the convective driving forces and of the stabilizing forces:

$$
R a=\frac{(\rho C) \rho_{f}}{\mu_{f}} g \frac{\beta k H \Delta T}{\lambda}
$$

where $\rho_{f}$ is the fluid density, $(\rho C)$ is the specific heat content of the equivalent continuous medium, $\beta$ is the fluid coefficient of thermal expansion, $\mu_{f}$ is the fluid dynamic viscosity, $g$ is the acceleration of gravity, $H$ is a reference height and $\Delta T$ is a reference temperature difference.

For a given configuration, the purely conductive regime (no fluid motion) is a solution of (A1)-(A3), then (A3) becomes

$$
\bar{\nabla} p^{\prime}=\operatorname{RaT}_{c} \bar{Y}
$$

which implies that the temperature does not vary along the $x$ space coordinate $\left(T^{\prime}{ }_{c}=T^{\prime}{ }_{c}(Y)\right)$. For geological bodies, this condition is exceptional and, where the hydraulic conditions allows it, free convection is a very likely phenomenon.

\section{APPENDIX 2: LOCAL EQUILIBRIUM REPRESENTATION OF MINERAL REACTION}

In a system composed of aqueous species and minerals, the slowest reactions control the rate of the global process. For diagenetic systems, the fluid-mineral reactions (heterogeneous reactions) are mostly slower than the aqueous ones, and therefore aqueous reactions can be considered to adjust instantaneously to chemical equilibrium relative to heterogeneous reactions. It is necessary, however, to determine whether these slower reactions are sufficiently rapid to attain bulk equilibrium state during species renewal at the mineral surface due to transport.

Local equilibrium represents the ultimate extent of the kinetic description when the kinetic term becomes infinity compared to the species renewal rate at the mineral surface. Mathematically, in this case, the fluid-mineral mass transfer rate approaches an indeterminable value that is zero multiplied by infinity, and the kinetic rate laws are replaced by algebraic constraints (i.e., the mass action equations (6) describing mineral equilibria).

The question of relevancy of the local equilibrium assumption (LEA) to describe transport and heterogeneous reaction processes has been addressed in recent papers [Knapp, 1989; Bahr, 1990; Lichtner, 1993]. In these studies, different mathematical approaches were used to describe the departure from, and the attainment of, equilibrium for selected configurations, the criterion being kinetic constant relative to fluid velocity according to a certain scale of interest. However, for multicomponent systems with competing reactions, the only way to ensure applicability of the local equilibrium approach is to compare results from a transport model based on LEA with those obtained using transport models incorporating dissolution/precipitation kinetics. But, because the mathematical solution tends to an indeterminate value when the system approaches equilibrium, the comparison of these two types of numerical models is generally unsuccessful for the slow fluid velocity in deep sedimentary aquifers. Nevertheless, the mathematical manipulations of the transport/reaction equations [Knapp, 1989; Bahr, 1990; Lichtner, 1993] emphasize that for sedimentary reservoirs where fluid moves at the kilometer scale due to regional hydraulic head or buoyancy, LEA could be valid (1) at the spatial scale of the representative elementary volume used in numerical models ( 1 to $10 \mathrm{~m}$ in the case of 100 - to $1000-\mathrm{m}$ structures) and (2) at the temporal scale of interest when studying the stage of porosity evolution (1000 years to $1 \mathrm{My}$ ). Generally, these calculations are made for cases where a disequilibrium impulse or maintained input is set, which is not the case in the present problem where the same water is continually recycled in a closed reservoir. In this case, because of the lack of external disequilibrium sources, the system would unconditionally evolve to thermodynamic equilibrium.

On the other hand, many studies have emphasized that, far from the inlet boundaries, the solution, moving at velocity of the order of a few meters per year, is generally close to equilibrium with the principal minerals of the rock [Connolly et al, 1990; Plummer et al., 1990; Moldovanyi and Walter, 1992; Coudrain-Ribstein and Gouze, 1993]. In these studies of borehole fluid analyses, authors consider generally that thermodynamic equilibrium occurs if the saturation index for minerals (i.e., the ratio of the activity product $Q$ of a given reaction to its equilibrium constant $K$ which is zero at equilibrium) is less than \pm 0.1 log unit for a large number of samples at different temperatures. This is because it is difficult to determine if these deviations from equilibrium correspond to a real oversaturation (or undersaturation), or to analytical errors on temperature and composition, or to uncertainties on values of in situ equilibrium constants.

The local equilibrium assumption (LEA) can be tested by comparing the rate of growth or dissolution of the minerals predicted with the LEA to the rate limited by kinetic laws. Far from equilibrium, the rate $\Omega$ of the mineral $i$ depends mainly on the mineral nature (kinetic constant $k$ and specific surface $S$ of reaction), the temperature $(T)$, the $p \mathrm{H}$ and the fractional content of this mineral in the rock $(F)$ :

$$
\Omega_{i} \sim k_{(i, T, p H)} S_{i} F_{i}
$$

For $p \mathrm{H}$ ranging from 6 to 8 , the slowest reaction among those considered in this study is the dissolution of silica. For sandstones, the model of close-packed spheres gives a good approximation of the fluid-silica surface area [Rimstidt and Barnes, 1980]. The rate of precipitation or dissolution decreases as the grain radius increases. For an average radius of $10^{-4} \mathrm{~m}$, the contact surface $S$ is $8 \times 10^{4} \mathrm{~m}^{2}$ $\mathrm{m}^{-3}$ of porous medium. Many features such as point defects, dislo- 
cations, microfractures or cavities tend to increase the fluid-mineral surface area as well as the replacement of quartz by amorphous silica or chalcedony. Therefore, in the model, the contact surfaces have been deliberately kept to the minimum value expected in sedimentary environments. The slower velocity constant $k$ of quartz dissolution is given by Knauss and Wolery [1988] with a value of 1.3 $X 10^{-6}$ mole per square meter of contact surface and per year at $25^{\circ} \mathrm{C}$ for a $p \mathrm{H}$ ranging from 5 to 8 . The value at any temperature is evaluated by Arrhenius' law using the activation energy for dissolution reactions given by Knauss and Wolery [1988] $\left(70 \times 10^{3} \mathrm{~J}\right.$ $\left.\mathrm{mol}^{-1}\right)$. Results are given in Figure 7 for different values of quartz contents in the rock. Theses values are directly compared to the rate of dissolution of silica predicted with the LEA model for a velocity of $0.1 \mathrm{~m} \mathrm{y}^{-1}$.

When the system approaches equilibrium, the rate $\Omega$ of the mineral $i$ depends on the saturation index in addition to the above cited parameters in order to account for the decreasing rate of dissolution or precipitation as $Q$ approaches $K$. The rate $\Omega$ is generally expressed as

$$
\Omega_{i} \sim k_{(i, T, p H)} S_{i} F_{i}\left(1-Q_{i} / K_{i}\right)
$$

Taking into account uncertainties in equilibrium constants and numerical limitations of the kinetic approach, it is useful to assume that macroscipic diagenetic events are comparable for both LEA and kinetic formulation as soon as the logarithm of the saturation index equals $0 \pm 0.1 \log$ unit. With the same procedure as above, one can compare the rate of dissolution of silica predicted with the LEA to the rate limited by kinetic laws for $Q=0.9 \mathrm{~K}$. Results are given in Figure 7 for different values of quartz contents in the rock.

In conclusion, Figure 7 shows that the quantity of silica that must be dissolved to achieve quasi-equilibrium (i.e., saturation index $=0$

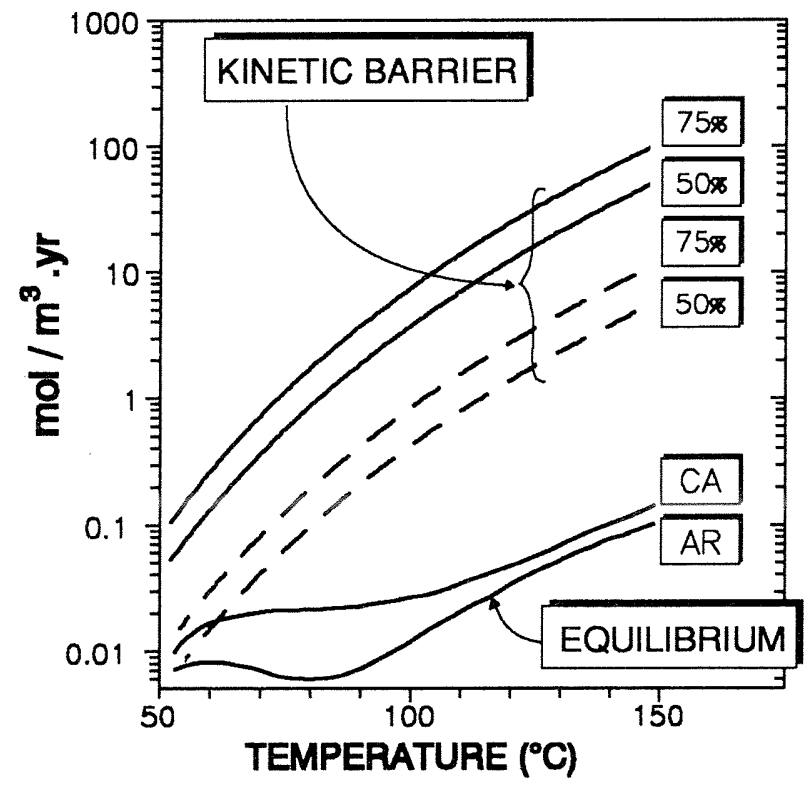

Fig. 7. Comparison between the rate of silica dissolution allowed by the kinetic processes far from equilibrium (solid curves) and close to equilibrium (dashed curves), and the rate of silica dissolution predicted by the local equilibrium assumption. Silica dissolution values bounded by kinetic processes are given depending on silica percentage in the rock ( 50 and $75 \%$ ) assuming a fluid-mineral reactive surface of $4 \times 10^{4} \mathrm{~m}^{2} \mathrm{~m}^{-3}$ and a kinetic rate of $1.3 \times 10^{-6} \mathrm{~mol} \mathrm{~m}^{-2}$ $\mathrm{y}^{-1}$. Predicted quantities of dissolved silica to ensure equilibrium conditions are given for the calcarenite model (CA) and the arkosic model (AR) for a velocity of $0.1 \mathrm{~m} \mathrm{y}^{-1}$, a slope angle of $20^{\circ}$ and a chloride content of $1 \mathrm{~mol} \mathrm{~L}^{-1}$. $\pm 0.1 \log$ unit) is small by comparison to the maximum quantities allowed by kinetic limitations for temperatures over $70^{\circ} \mathrm{C}$. Although these results do not give any information of kinetic effects on chemical process, it proves at least that kinetic barriers are not jumped during modeling even in the most unfavorable cases studied in this paper. However, in the case of the calcarenite model (CA) and for temperatures below $70^{\circ} \mathrm{C}$, the rate of silica transfer predicted with the LEA model can exceed the rate allowed by the kinetic model. In this case, the rate of porosity evolution calculated at very small depth for fluid velocity on the order of $0.1 \mathrm{~m} \mathrm{y}^{-1}$ represents the maximum limit in the case of the calcarenite model.

Acknowledgments. The authors are grateful for the constructive discussions with Guy Vasseur, Ghislain de Marsily and David Chapman. They wish to thanks reviewers (Jean Bahr, Richard B. Knapp and the associate editor) for their helpful comments and Gunilla de Marsily and Marguerite Godard for English language corrections. The permission of research group on basin modeling 'TRAnsferts dans les BASsins' (C.N.R.S - A.G.I.P - I.F.P. - E.A.P.) to publish the results of this study is also gratefully acknowledged.

\section{REFERENCES}

Bahr, J.M., Kinetically influenced terms for solute transport affected by heterogeneous and homogeneous classical reactions, Water Resour. Res., 26, 21-24, 1990.

Bernard, D., Convection naturelle dans les structures géologiques poreuses: Deux exemples numériques, Bull. Mineral., 111, 601-611, 1988a.

Bernard, D., Convection naturelle dans une couche géologique poreuse inclinée, in Proceedings of the First International Confer ence in Africa on Computer Methods and Water Ressources, Computational Mechanics, edited by D. Ouazar and C.A. Brebia, vol. 5, pp. 59-70, Springer-Verlag, New York, $1988 b$.

Bernard, D. and P. Menegazzi, Natural convection in geological porous structures: A numerical study of the 2D/3D stability problem, in Computational Methods in Subsurface Hydrology, Computational Mechanics, edited by G. Gambolati et al., pp. 315-320, Springer-Verlag, New York, 1990.

Bernard, D., M. Danis and M. Quintard, Effect of permeability anisotropy and throw on the transmisivity in the vicinity of a fault in AGU Monograph on Hydrogeological Regimes and Their Subsurface Thermal Effects, Geophys. Monogr. Ser., edited by A.E. Beck, L. Stenega and G. Garden, vol. 47, pp. 119-128, AGU, Washington, 1989.

Bethke, C.M., Modeling subsurface flow in sedimentary basins, Geol.Rundsch., 78, 129-154, 1989.

Bjorlykke, K., A. Mo and E. Palm, Modelling of thermal convection in sedimentary basins and its relevance to diagenetic reactions, Mar.Pet. Geol., 5, 338-351, 1988.

Blanchard, P.L. and J.M. Sharp, Jr., Possible free convection in thick Gulf Coast sandstone sequences, in Transactions, Southern Section, edited by C.L. McNulty and J.M. McPherson, pp. 6-12. American Association of Petroleum Geologists, Fort Worth, Tex., 1985.

Brigaud, F. and G. Vasseur, Mineralogy, porosity and fluid control on thermal conductivity of sedimentary rocks, Geoph. J. Int., 98, 525-542, 1989

Castinel, G. and M. Combarnous, Convection naturelle dans une couche poreuse anisotrope, Rev. Gén. Therm., 168, 937-947, 1975. Cermak, V. and L. Rybach, Thermal conductivity and specific heat of minerals and rocks: 1 -a, in Physical Properties of Rocks edited by G. Angenheister, pp. 305-343, Springer-Verlag, New York, 1982. Combarnous, M.H. and K. Aziz, Influence de la convection naturelle dans les réservoirs d'huile ou de gaz, Rev. Inst. Fr. Pét., $X X V-12$, 1335-1353, 1970.

Combarnous, M.H. and D. Bernard, Modelling of free convection in 
porous media: From academic cases to real configurations, $A d v$. Hydrosci., 10, 231-307, 1988.

Combarnous, M.H. and S.A. Bories, Hydrothermal convection in saturated porous media, paper presented at the 25th National Heat Transfer Conference of ASME, International Symposium on Convection in Porous Media: Non-Darcy Effects, Am. Soc. of Mech. Eng., Houston, Tex., 1975.

Connolly, C.A., Walter L.M., Baadsgaard H. and F.J. Longstaffe, Origin and evolution of formation waters, Alberta Basin, Western Canada sedimentary Basin, Appl. Geochem., 5, 375-395, 1990.

Coudrain-Ribstein, A., Transport d'éléments et réactions géochimiques dans les aquiferes, Th. Docteur, Univ. de Strasbourg I and Ecole des Mines de Paris, France, 1988.

Coudrain-Ribstein A. and $\mathrm{Ph}$. Gouze, Quantitative study of geochemical processes in the the Dogger aquifer, Paris Basin, France, Appl.Geochem., 8, 495-506, 1993.

Coudrain-Ribstein, A. and P. Jamet, Choix des composantes et spéciation d'une solution, C. R. Acad. Sci., Ser. 2, 309, 239-244, 1989.

Coudrain-Ribstein, A. and G. de Marsily, Modelling of mass transfer arising from buoyancy flows in sedimentary basins, Sci.Géol.Bull., 42(4), 299-312, 1989.

Criss, R.E. and A.M. Hofmeister, Application of fluid dynamic principles in tilted permeable media to terrestrial hydrothermal systems, Geoph.Res. Lett., 18(2), 199-202, 1991.

Fritz, B., Etude thermodynamique et modélisation des réactions hydrothermales et diagénétiques, Sci. Géol. Mem., 65, 176-183, 1981.

Genthon, P., M. Rabinowicz, J.P. Foucher and J.C. Sibuet, Hydrothermal circulation in an anisotropic sedimentary basin: Application to the Okinawa back arc basin, J. Geophys. Res. 95(12), 19,175-19,184, 1990.

Giles, M.R., Mass transfer and problems of secondary porosity creation in deeply buried hydrocarbon reservoirs, Mar. Pet. Geol., 4, 188-204, 1987

Giles, M.R. and R.B.Boer, Origin and significance of redistributional secondary porosity, Mar.Pet. Geol., 7, 378-396, 1990.

Goblet, P., Programme METIS - Simulation d'écoulement et de transport miscible en milieu poreux et fracturé - notice de conception, Rap. LHM/RD/89/23, Ecole Nationale Supérieure des Mines de Paris, France, 1989.

Horai, K., Thermal conductivity of rock-forming minerals, J. Geoph. Res., 76, 1278-1308, 1971.

Hutcheon, I., Carbon dioxide in clastic rocks and silicate hydrolysis, Geology, 18, 541-544, 1990.

Knapp, R.B., Spatial and temporal scales of local equilibrium in dynamic fluid-rock systems, Geochim. Cosmochim. Acta, 53, 1955-1964, 1989.

Knauss, K.G. and T.J. Wolery, The dissolution kinetics of quartz as a function of $p \mathrm{H}$ and time at $70^{\circ} \mathrm{C}$, Geochim. Cosmochim. Acta, 52, 43-53, 1988

Lichtner, P.C., Scaling properties of time-space kinetic mass transport equations and the local equilibrium limit, Am. J. Sci., 293, 257-296, 1993.

Ludvigsen, A. and E. Palm, Convective momentum and mass transport in porous sloping layers, J. Geophys. Res., 97(9), $12,315-12,325,1992$.

Marsily, G. de, Quantitative Hydrogeology, Academic, San Diego, Calif., 1986.

Menegazzi, P., Convection naturelle dans les structures géologiques poreuses: Etude numérique bidimentionnelle et stabilité des écoulements, Th. Doct., Univ. de Bordeaux, France, 1989.

Michard, G., Recueil des données thermodynamiques concernant les équilibres eaux-minéraux dans les réservoirs hydrothermaux, Rep. C.C.E. E.U.R 8590 FR, edited by the European Community Commission, Brussels, 1983.

Michard, G., Equilibres Chimiques dans les Eaux Naturelles, Publisud, Paris, France, 1989.
Moldovanyi, P. and L.M. Walter, Regional trends in water chemistry, Smackover Formation, Southwest Arkansas : Geochemical and physical control, AAPG Bull., 76, 864-894, 1992.

Moore, C.H., Carbonate Diagenesis and Porosity, Developments in Sedimentology, vol 46, Elsevier, New York, 1989.

Morel, F.F.M., Principles of Aquatic Chemistry, John Wiley, New York, 1983.

Nagy, K.L., C.I. Steefel, A.E. Blum and A.C. Lasaga, Dissolution and precipitation kinetic of kaolinite: Initial results at $80^{\circ} \mathrm{C}$ with application to porosity evolution in sandstones, AAPGMem., 49, 85-102, 1990.

Nordstom, D.K., L.N. Plummer, D. Langmuir, E. Busenberg, H.M. May, B.F. Jones and D.L. Parkhurst, Revised chemical equilibrium data for major water-mineral reactions and their limitations, in Chemical Modeling of Aqueous System II, pp. 398-413, American Chem. Soc., Washington, D.C., 1990.

North, F.K., Petroleum Geology, Allen and Unwin, Winchester, Mass., 1985.

Palm, E., Rayleigh convection, mass transport and change in porosity in layers of sandstone, J. Geophys. Res., 95(6), 8675-8679, 1990.

Phillips, O.M., Flow and Reactions in Permeable Rocks, Cambridge University Press, New York, 1991.

Plummer, L.N., J.F. Busby, R.W. Lee and B.B. Hanshaw, Geochemical modeling of the Madison aquifer in Parts of Montana, Wyoming, and South Dakota, Water Resour. Res., 26, 1981-2014, 1990.

Price, L.C., Primary petroleum migration by molecular solution: consideration of new data, J.Pet. Geol., 4-2, 195-223, 1981.

Rabinowicz, M., J.L. Dandurand, M. Jakubowski, J. Schott and J.P. Cassan, Convection in a North Sea oil reservoir: Inferences on diagenesis and hydrocarbon migration, Earth Planet. Sci.Lett., 74, $387-404,1985$

Riahi, N., Non linear convection in porous layer with finite conducting boundaries, J. Fluid Mech., 129, 153-171, 1983.

Rimstidt, J.D. and H.L. Bames, The kinetic of silica-water reactions, Geochim. Cosmochim. Acta, 44, 1683-1699, 1980.

Smith, J.T. and S.N. Ehrenberg, Correlation of carbon dioxide abundance with temperature in clastic hydrocarbon reservoirs: Relationship to inorganic chemical equilibrium, Mar.Pet. Geol., 6, 129-136, 1989.

Straus, J.M. and G. Shubert, Thermal convection of water in porous medium: Effects of temperature- and pressure-dependent thermodynamic and transport properties, J. Geophys. Res., 82(2), 325-333, 1977.

Tardy, Y. and J.P. Cassan, Hypothèse sur la circulation convective des fluides de la diagenèse. Minéralogie et pétrologie des réservoirs gréseux de l'Infrasalifere de Gabon, C. R. Acad. Sci., Ser. 2, 293, 587-592, 1981.

Wood, J.R. and T.A. Hewett, Fluid convection and mass transfer in porous sandstones - a theoretical approach, Geochim. Cosmochim. Acta, 46, 1707-1713, 1982.

Wood, J.R. and T.A. Hewett, Reservoir diagenesis and convective fluid flow, AAPG Mem., 37, 99-110, 1984.

Wooding, R.A., Large-scale geothermal field parameters and convection theory, N.Z.J.Sci.21, 219-228, 1978.

D. Bernand, Laboratoire 'Energetique et Phénomènes de Transfer.' U.R.A CNRS 873, Ecole Nationale Supérieure d'Arts et Métiers, Université de Bordeaux I, F-33405 Talence cedex, France.

A. Coudrain-Ribstein, Laboratoire de Géophysique, E.R.S CNRS 1367, Université Pierre et Marie Curie, F-75252 Paris cedex 05, France.

Ph. Gouze, Centre Géologique et Géophysique, E.R.S CNRS 082, Université de Montpellier II, F-34095 Montpellier cedex 05, France.

(Received November 10, 1992; revised June 29, 1993. accepted August 26, 1993.) 